\author{
S. B. Perelman, M. Omacini, P. M. Tognetti \& W. B. Batista
}

\title{
Pampean-grassland heterogeneity on the intersection of science, art, and culture*
}

\begin{abstract}
Perelman, S. B., Omacini, M., Tognetti, P. M. \& Batista, W. B.: Pampean-grassland heterogeneity on the intersection of science, art, and culture. — Bocconea 28: 59-75. 2019. — ISSN: 11204060 printed, 2280-3882 online.

Since prehistoric times, temperate grasslands have provided favorable habitat for human subsistence. Ease of exploitation, however, has caused that temperate grasslands are among the most destroyed terrestrial ecosystems. The region known as the Pampas or Rio de la Plata Grasslands, extending over some 750,000 sq. km in central eastern Argentina, Uruguay and southern Brazil, comprises the largest temperate grassland area in the southern hemisphere. Flat topography, humid temperate climate, grassy natural vegetation, and absence of large native herbivores have conditioned multiple aspects of human life in the region, like patterns of population settlement, techniques for acquisition and transportation of goods, aesthetic preferences, and social structure. In this article, we present some writers inspired by the Pampas, we briefly summarize the main results of scientific research on the drivers of vegetation physiognomy and heterogeneity in the Pampas, based on the invaluable floristic database compiled by Professor Rolando J. C. León, and we sketch one of Professor León's scientific-historic tours to the Pampas. Finally, we call attention to currently threats to the persistence of Pampean Grassland.

Key words: Rio de la Plata grasslands, climatic drivers, vegetation survey, biological invasions.
\end{abstract}

\section{Introduction}

Temperate grasslands have provided habitat for human subsistence since prehistoric times. These ecosystems, characterized by open grassy vegetation, occur in regions where factors such as drought, fire, or herbivory have prevented tree dominance (Walter 1970; Bond \& Keeley 2005; Sankaran \& al. 2008). Grasslands have been recognized and appreciated around the world, receiving local names like prairies, veldts, or pampas, and have become home for some renowned cultures. In these regions, cultural and economic history cannot be dissociated from the characteristic provision of basic resources for human life, so readily accessible for use for animal herding and agriculture. Ease of exploitation, how-

\footnotetext{
*Article first published online on 20 December 2018 in Flora Mediterranea 28: 313-329.
} 
ever, has caused that temperate grasslands are among the terrestrial ecosystems with highest extension of destroyed area and smallest proportion of area devoted to nature protection (Hoekstra \& al. 2005).

The region known as the Pampas or Rio de la Plata Grasslands, extending over some 750,000 sq. km in central eastern Argentina, Uruguay and southern Rio Grande do Sul in Brazil, from $28^{\circ} \mathrm{S}$ to $38^{\circ} \mathrm{S}$, comprises the largest temperate grassland area in the southern hemisphere (Hudson 1895; Parodi 1947; Cabrera 1976; Soriano 1992; Gibson 2009). The essential characteristics of this vast region are flat topography, humid temperate climate, natural vegetation dominated by coarse grasses with virtually no trees, and absence of large native herbivores. These characteristics have conditioned multiple aspects of human life in the region, from patterns of population settlement, to techniques for acquisition and transportation of goods, perceptions and appreciations of space, time, and effort, aesthetic preferences, social structure, and the history of human competition for resources and power. Since the arrival of the Spaniards to the Río de la Plata in the sixteenth century, aboriginal peoples from the Pampas were gradually displaced from the plains (Hudson 1895). This determined a deep transformation in the pattern of land occupation and use, as the aboriginals had lived in nomadic communities wandering on the plains in the pursuit of livelihood, whereas the European colonists who replaced them settled as small groups on fixed locations widely separated from each other (Sarmiento 1874). After European settlement, the land was incorporated into cattle herding. As a result, vegetation physiognomy and landscape structure of the Pampas started a process of unprecedented changes. Tall dominant grasses were replaced by shorter gramineous species and exotic forbs by effect of fire and grazing by confined animals, and runoff patterns were deeply modified by canals, railways, and later by roads and highways constructed across the region (Hernández 1882; Hudson 1895; Sbarra 1964). In recent decades, the area devoted to cattle production was greatly reduced due to the expansion of increasingly sophisticated crop agriculture (Baldi \& al. 2006; Viglizzo \& al. 2011). This is resulting in further transformations of the Pampas, where nowadays vegetation comprises large areas of species-poor crop fields and fallow land covered by short turf or invaded by shrubs or exotic trees, and human-population density has dropped dramatically (Ghersa \& al. 2002; Hora 2018).

Because the national economy is highly dependent on agricultural exports, the history of exploitation of the Pampas has been in good measure modulated by state initiatives. These range from the historical distribution of land, to the building of transportation infrastructure, interventions in the market of agricultural products and services, and the continued development of technology and human resources. In particular, botanical studies of the Pampas, acquired impulse in the twentieth century in the context of state universities and research institutes. Distinguished botanists produced a corpus of knowledge of plant taxonomy and phytogeography that has served as the basis for a currently active field of ecological research in the region. An essential contribution to the progress of vegetation ecology in the Pampas is the life-long work of Professor Rolando J.C. León (1932 - 2015) to characterize their compositional heterogeneity. Systematic vegetation surveys conducted over the years by Professor León and his disciples across the region produced an invaluable database of floristic information that allows exploring the drivers of species distribution and community composition at varying spatial scales, and serves as a detailed reference for assessing the ongoing transformation of the grassland. In addition, Professor León 
was an extremely active and committed educator who, both in and outside the academy, taught botany and ecology as articulated with history, art, and literature in the Pampas and elsewhere. He often led students and researchers from overseas on scientific-historic tours across the Pampas to appreciate the amazing natural diversity concealed under the apparent homogeneity of the grassland. In this article, we present some art and literature inspired by landscape of the Pampas, we give a brief summary of the main results of scientific research on the drivers of the physiognomy and heterogeneity of vegetation in the Pampas, and we sketch one of Professor León's scientific-historic tours to the Pampas. Finally, we call attention to current threats to the persistence of Pampean Grassland.

\section{Literature}

Since colonial times, Argentine culture has been marked by a tension between contrasting valuations of countryside and city life experiences. This tension originates, at least in part, in the fact that Spanish conquerors had little interest in the Pampas, as the grassland offered neither precious metals nor abundant people to enslave, and concentrated their attention on the services produced by the cities (Hora 2018). For them, the plain appeared as an obstacle for travelling and transportation, especially because of the lack of navigable waterways, the difficulty for finding water, and the softness of the soil, where vehicles often became stuck in the mud (D'Orbigny 1998). Under this tension, rural and city people of the Pampas have tended to look on each other with suspicion (D'Orbigny 1998; Sarmiento 1874) and developed two separate literary traditions.

Rural people, the gauchos, produced a type of anonymous orally-transmitted poetry (known as payada) reflecting their refusal to accept rules, intolerance to alien manners, violence, and a mixture of melancholy and witty irony associated with the harshness and isolation of their lives (D'Orbigny 1898; Sarmiento 1874). This literary genre entered in the cannon of Argentine literature when José Hernández published his epic poem Martín Fierro in 1872: "Mi gloria es vivir tan libre / Como el pájaro del cielo: / No hago nido en este suelo / Ande hay tanto que sufrir, / Y naides me ha de seguir / Cuando yo remuento el vuelo" ("My glory is to live as free / as the bird in the skies: / I don't nest in this land / where there's so much to be suffered / and nobody shall follow me / when I take flight"). It also shows up in the well-appreciated Argentine folklore, as for example in Coplas del payador perseguido by Atahualpa Yupanqui: "Yo sé que muchos dirán / que peco de atrevimiento / si largo mi pensamiento / pal rumbo que ya elegí / pero siempre he sido ansi; /galopiador contra el viento..." ("I know that many will say / I'm falling into impertinence / if I let my thoughts go free/ the way I've already chosen / but I've always been so / a galloper against the wind...").

In the cities, an abundant literature produced by cultured writers has reflected the environment and the life in the Pampas. Writers in this tradition have been people with a strong rural experience often because they belonged to landowner families or had otherwise grown up or travelled extensively in the countryside. Here we can only mention a few examples.

A recurrent theme in this literature is the incommensurability and emptiness of the plain, making it difficult to discriminate land from sky. See for example a fragment of the epic La Cautiva, by Esteban Echeverría (1837): "Gira en vano, reconcentra / su inmensidad, y 
no encuentra / la vista, en su vivo anhelo / do fijar su fugaz vuelo / como pájaro en el mar ..." ("Spins in vain, gathers / its immensity, and fails / the eager eye to find /where to rest its fleeting flight/ like a bird over the sea ..."); or this one of Facundo, the foundational essay by Domingo F. Sarmiento (1874): “ ... el horizonte siempre incierto, siempre confundiéndose con la tierra entre celajes y vapores tenues que no dejan en la lejana perspectiva señalar el punto donde el mundo acaba y principia el cielo" ("... the horizon ever uncertain, ever confused, with the land among cloudscapes and thin vapors that impede fixing in the far distance the point where the world ends and the sky begins."). The vastness of the plain has also provoked the awe from the celebrated writer Jorge Luis Borges in his story El Fin (Ficciones, 1944): "Hay una hora de la tarde en que la llanura está por decir algo; nunca lo dice o tal vez lo dice infinitamente y no lo entendemos, o lo entendemos pero es intraducible como una música..." ("There is a time in the afternoon when the plain is on the verge of saying something. It never says it, or perhaps it says it endlessly and we fail to understand it, or we understand it butit is untranslatable like music ..."). The immensity of the plain and the comparative minuteness of the plants covering it are the likely causes of the literary preference for a panoramic view. Some authors, however, have displayed also amazing powers of description at conveying a closer view of elements from the Pampas, though often choosing the once relatively exceptional trees. See for example, a gaze on a tala (Celtis ehrenbergiana (Klotzsch) Liebm.) thicket by Sara Gallardo in her novel Los galgos, los galgos (1968): "No era solo de talas ese monte sino también y en segundo grado de acacias negras, individuos de cuerpo gris, medio calvos, con hoja fresca pero insuficiente, como señores de edad mediana irreprochables y tediosos de los cuales uno solo, que zumbaba como un poste eléctrico, nos inspiró interés. Cuando su examen nos condujo a un agujero hirviente de abejas emprendimos la retirada." ("Not just oftalas was that thicket but also and in second term of black acacias, gray bodied individuals, halfway bald, with fresh though insufficient leaves, like irreproachable and boring middle-aged gentlemen among which only a single one, which buzzed like an electric pole, attracted our attention. When the examining of it took us to a hole boiling with bees, we marched in retreat.").

\section{Scientific research}

While documenting patterns of landscape heterogeneity through rigorous observation and quantitative methods, Dr. Rolando León and his disciples contributed to the construction of a large database of floristic evidence. The information contained in this database allowed answering interesting questions about determinants of diversity at different scales. As part of those studies, it was necessary to geo-reference some vegetation samples to allow them to be linked with climatic and land use information. While doing this, it was surprising to find at each step, that Google Earth images seemed copied from the field map made by Dr. Rolando León during the '70s in the era before the GPS (Fig. 1).

On the broadest scale, a recent overview involving studies in Brazil, Uruguay and Argentina (Andrade \& al. 2018) explored the complete gradient in floristic composition over the entire extension of the Pampean Grasslands to generate the consensus species list, a first step towards enhanced understanding of the biogeography and ecology in the Rio de 


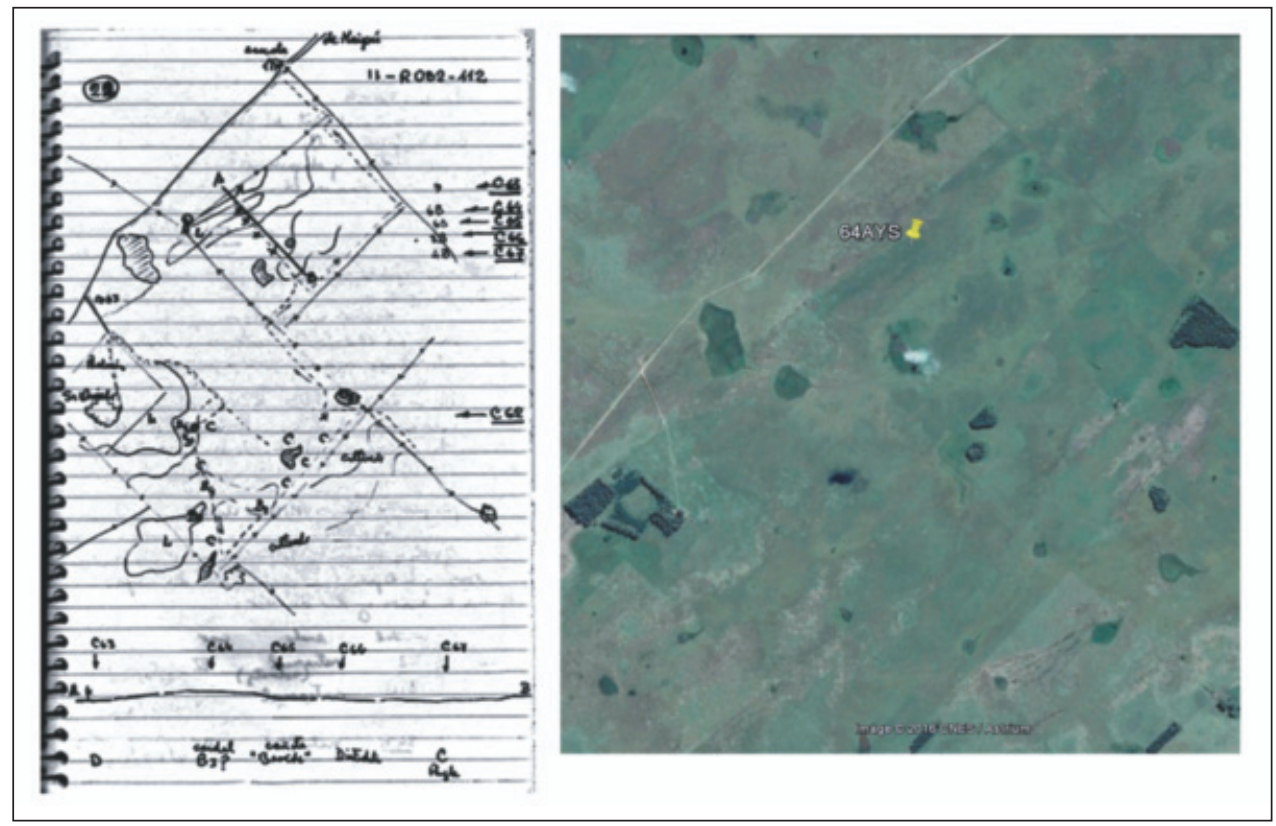

Fig. 1. Vegetation releves were georeferenced to generate links with the climatic and land use information.The capture from Google Earth seemed copied from the field map made by Dr. León in the era before GPS.

la Plata grassland biome. The number of almost 5 thousand vascular plant species across a total extent of $750000 \mathrm{~km}^{2}$ clearly establishes the Río de la Plata grasslands as a highly biodiverse region in South America. The high species richness found in this region is likely due to its location in a biogeographical overlap zone: the subtropical to temperate transition (Andrade \& al. 2018). The East-West gradient in vegetation heterogeneity was also studied for remnant grasslands located on high agronomic potential soils along a five degree-east-west transect in the Rolling Pampa (Burkart \& al. 2011). In this gradient the main driving factor of floristic heterogeneity was water availability, determined by climate and soil characteristics. These remnant grasslands which cover small areas as isolated stands are hot spots of native biodiversity(Fig. 2), as more than $80 \%$ of the species recorded in early vegetation surveys are still present there (Burkart \&al. 2011).

Another study focused on the zonal community (mesophytic grasslands) but spread over a large scale (i.e. along a $600 \mathrm{~km}$ gradient of five degrees latitude) assessed the relative importance of climate and land fragmentation by agriculture as controls of the diversity and composition of the grasslands (Perelman \& al. 2017). Mesophytic grasslands on fertile soils, which have been largely replaced by crops due to their agricultural aptitude, are surrounded by matrices with varying proportions of remnant grassland and crop fields in different Pampean subregions (Baldi \&al. 2006; Viglizzo \& al. 2011). A multivariate analysis method applied to order samples using as the sole input the list of plant species present in each site, with no addition of any geographical or climatic information, revealed the exis- 


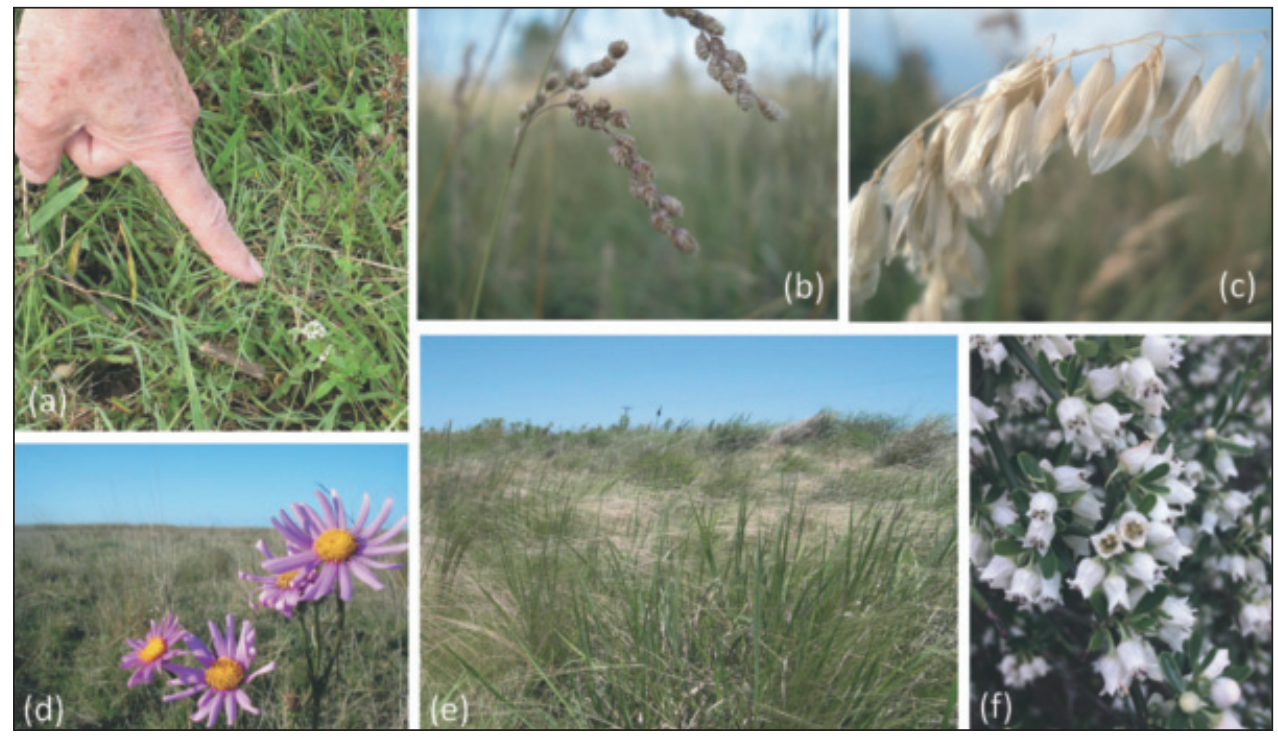

Fig. 2. Details of native species embellishing the grassland in the Pampas. The textures and colors of grasses and forbs certainly enhanced the beauty of these lands, inspiring naturalist and artists. (a) The hand of Prof. Rolando León pointing to Borreria dasycephala (Cham. \& Schltdl.) Bacigalupo \& E.L. Cabral. This white flowered forb is a cool-season species characteristic of mesophytic meadows across the Pampas (Leon \& al. 1979; Burkart \& al. 1990). (b) Briza subaristata Lam. and (c) Melica brasiliana Ard. are cool-season grasses that co-dominate grassland (Burkart \& al. 2011). Flowers and fruits of these grasses embellish the grassland during December. (d) The colorful Senecio pulcher Hook. \& Arn. contrasts with the grayish-green background of the Flooding Pampa grasslands during early summer. This yellow hearted daisy is the delight of both, bugs and photographers. (e) View of a tussock grassland. The combination of cool-season (e.g. Nasella trichotoma (Nees) Hack. ex Arechav, golden spikes) and warm-season grasses (e.g. P. quadrifarium Lam., green tussock leaves) maintains continued primary production in the year. (f) The delicate flowers of Discaria americana Gillies \& Hook. contrast with their strong, pugnant aroma. This shrub is typical of the western, sandy grassland of the Inland Pampa. Photos: (a) Marina Omacini. (b-f) Pedro Tognetti.

tence of species turnover among the mesophytic grasslands of different subregions (Perelman \& al. 2017). But, more surprisingly the pattern of site distribution in the ordination graph resembled the geographic location of the samples!. Underlying variables controlling the water-energy dynamics: mean annual precipitation, inter-annual precipitation variability and minimum temperature are associated to latitude in this region. At the same time landscape fragmentation and variability of intra-annual precipitation are related to continentality or distance from the Atlantic Ocean. Climatic factors associated to latitude were also strong determinants of regional diversity: gamma diversity decreased linearly with increasing distance from the Equator, as did the rate of species accumulation with expanding area. By contrast, the current diversity in the sites of remnant vegetation showed association with the pattern and intensity of agricultural perturbation, as local species richness was more influenced by landscape fragmentation and remaining grassland 
cover. Moreover, the main environmental factor that explained the variation in local richness in multiple regression models was mean patch size of native grassland (Perelman \& al. 2017). It seems that local diversity in these zonal grasslands is no longer coupled with factors linked to biogeographic, evolutionary and dispersal history that modeled the regional flora and still drive gamma diversity.

In previous studies, we analyzed cross-scale vegetation patterns in a more limited $90000 \mathrm{~km}^{2}$ area of natural grasslands in the Flooding Pampa where most of the area was still devoted to extensive rangeland (Fig. 3a \& 3b; Perelman \& al. 2001, 2007). In the Flooding Pampa, soil salinity and flooding are the primary underlying cause of coordinated species turnover. At very fine spatial scales associated with topographic features that determine the intensity and duration of the floods we can observe large proportion of the entire variation in species composition. The main floristic change is related to topographic differences, sometimes just a few meters apart but more often only tens of centimeters, that determine the intensity and duration of the floods, and to halomorphic differences of the
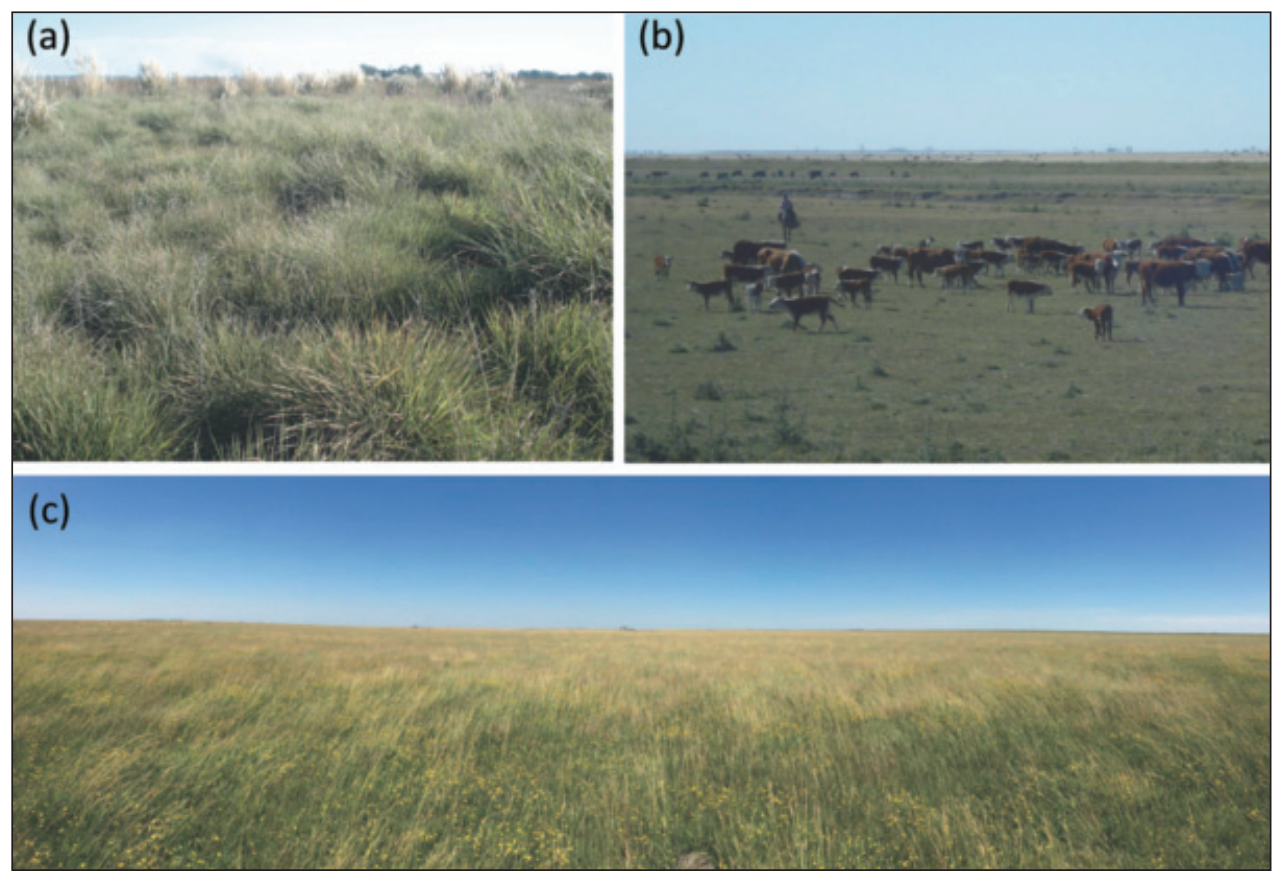

Fig. 3. Landscape views of the Pampas, with their infinite horizon. (a) Grassland stand near C. Casares, Buenos Aires, dominated by tall tussock grasses, Paspalum quadrifarium Lam. and Cortaderia selloana (Schult. \& Schult. f.) Asch. \& Graebn. These two species might have formed the matrix in the pristine communities. (b) Gauchos herding cattle, near Pila, Buenos Aires. Cattle, sheep, and horses introduced by Europeans deeply changed the physiognomy of the Pampas (Hudson 1895). (c) Early summer view of a grassland in the Flooding Pampa, near Pila, Buenos Aires. Across the region, the grassland hosts numerous exotic species like Lolium multiflorum Lam., the gold colored grass, and Lotus tenuis, the yellow flowers (Perelman \& al. 2007). Photos: Pedro Tognetti. 
soils (Batista \&León 1992; Batista \& al. 2005; Burkart \& al. 1990). The most extended communities are those exposed to prolonged floods where the dominant species are Setaria geminate Forssk, Leersia hexandra Sw., Danthonia montevidensis Hack. \& Arechav., Nassella formicarum (Delile) Barkworth, Paspalum dilatatum Poir., Eleocharis species, Jarava plumosa (Spreng.) S.W.L. Jacobs \& J. Everett, Nassella neesiana (Trin. \& Rupr.) Barkworth and Panicum gouinii E. Fourn., and those exposed to brief floods, with important presence of Bromus catharticus Vahl, Piptochaetium stipoides (Trin. \& Rupr.) Hack. ex Arechav., P. bicolor (Vahl) E. Desv., Melica brasiliana Ard. , Nasella trichotoma (Nees) Arechav., Paspalum dilatatum Poir., Jarava plumose (Spreng.), Nasella neesiana (Trin. \& Rupr.) Barkworthand Bothriochloa lagurioides (DC.) Herter. These grasslands received a very important contribution both in species richness and biomass of alien species introduced with European colonization and domestic livestock. Functional group composition differed widely between the native flora dominated by perennial species in equal proportions of grasses and herbs and the exotic flora with predominance of annual winter-growing herbs of euroasiatic origin (Fig. 3c; Perelman \& al. 2001, 2007; Poggio \& al. 2015). Moreover, revisited grassland exposed to moderate grazing intensity during $35 \mathrm{yr}$ (Fig. 4) showed clear differences in richness changes, in degree of homogenization and in species turnover during this period (Puhl \& al. 2014), suggesting that the effect of human activities varies among plant communities.

The lack of trees in the Pampas intrigued scientists and travelers visiting these remote lands (Darwin 1878;Schmider 1929; Walter 1967; Yasawa 1989). Interestingly, at the time of Spaniard settlement, some native woody species (e.g. Phytolaca dioica L., Acacia bonaerensis Hook. \& Arn., Celtis erhenbergiana (Klotzsch) Liebm.) were concentrated along river banks or ancient calcareous shell deposits (Ghersa \&al. 2002; Ellenberg 1962), but until quite recently the plain was covered exclusively by grasslands. The fact that an area with an average annual rainfall of 600-1000 $\mathrm{mm}$ was not covered by forests originated a centennial discussion (Walter 1967; Chaneton \& al. 2012), without a unique solution and
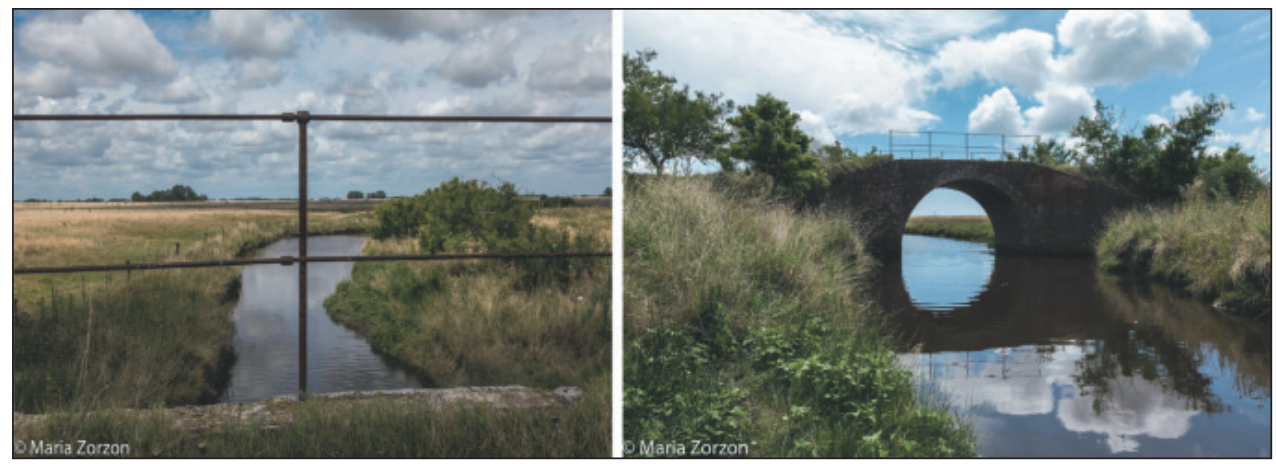

Fig. 4. View (left) from the bridge (right) over the Buñirigo stream in the North of the Flooding Pampa, near the places where Rolando León, Silvia Burkart and Chiara Movia began the first inventory of physiography and plant communities of the region (Leòn \& al. 1979), one of the sites resurveyed after 35 years (Puhl \& al. 2014). Photo credit María Zorzón. 
with multiple hypotheses (Yazawa 1989). For example, Darwin (1878) suggested that wind would be limiting forest development, whereas Ulrich Schmieder (1929) proposed that it is an anthropogenic grassland originated from the use of fire. This discussion generated "The Pampas problem", as a special case of grasslands existing under these climatic conditions (Schmieder 1929). Lately, other hypotheses were based on water deficit, on soil mineralogy, and on climatic fluctuations (Walter 1967), also on the geological youth of this region (Parodi 1940; Chaneton \& al. 2012), and on the competitive exclusion of tree seedlings by grasses (Parodi 1940; Facelli \& Leon 1986; Chaneton \& al. 2012). Whatever the cause, the limits of the Pampas grassland with the shrub steppes and xerophytic forests that surround it were delineated many times (León \& Anderson 1983).

Nowadays trees have become a central element in the life and culture of the inhabitants of the Pampas. Both trees and settlers are newcomers to these lands, with the colonial advance and the establishment of new land uses increased tree abundance (Ghersa \& León 2001; Ghersa \&al. 2002). On the one hand, native woody species such as Acacia bonaerensis Hook. \& Arn., or Celtis erhenbergiana (Klotzsch) Liebm., were planted (and nursed!) mainly to be build vegetated fences, limiting the movement and giving shelter to livestock (Sbarra 1964; Ghersa \& León 2001). On the other hand, the greatest woody advance was from exotic tree species (Zalba \& Villamil 2002; Ghersa \& al. 2002), including species of numerous genera such as Eucalyptus and Casuarina from Australia, Fraxinus, Pinus, and Gleditsia from North America, Ulmus, Platanus, Ligustrum and Melia from the Eurasia Acacia and Phoenix from Africa, etc.

Currently the main concern of Pampean scientists and landowners, it is not the lack of trees but the spontaneous woody establishment and invasion. Different species of trees encroach over agricultural lands, pastures, and grasslands throughout the entire region (Zalba \& Villamil 2002; Ghersa \& al. 2002; Mazia \& al. 2010), blocking the typical Pampas' horizon. Even though native woody species are still present, conspicuous tree establishment and invasion involves exotic species. For instance, Melia azedarach L. invades grasslands and savannas in the eastern areas, while the European Ulmus invades pastures and roadsides in the driest grassy areas of the west (Facelli \&Leon 1986). The invasion of Gleditsia triacanthos L. in the Pampas grasslands has been well-studied (Mazia \& al. 2001; Chaneton \& al. 2004; Mazia \& al. 2010; 2013). Supporting the idea of a climatic constraint to the establishment of trees, the invasion of $G$. triacanthos is more pronounced in humid years (Mazia \& al. 2010). Interestingly, seed predation by rodents was higher for native than for exotic tree species (Busch \& al. 2012), suggesting a differential biological filter among native and exotic species. Together, these evidences contribute to the idea that the geomorphological youth of the Pampas could limit the generation of genotypes adapted to these climatic conditions that, together with grass competition and periods of drought, could limit the advance of native trees in the pampas (Walter 1967; Chaneton \& al. 2012).

\section{An ecological and cultural journey into the Pampas}

We propose a $700 \mathrm{~km}$ journey into the field to recognize the heterogeneity of the Pampas and to explore remnants of the natural grassland (Fig. 5). The journey covers two 
sub regions with contrasting relief, hydrology, and land-use history, first the Rolling Pampas, and second the Flooding Pampa, the highest expression of the Pampas flat spirit (Oyarzabal \& al. 2018). A good supplementary reading for our journey is Ghersa \& Leon (2001), who provide descriptions of present-day Pampean landscape and its history since the arrival of Europeans and the introduction of cattle.

Our trip begins by travelling to the north of the city of Buenos Aires, across the Rolling Pampas, where fluvial landforms offer the background to the visible imprint of culture (Ghersa \& Leon 1999, 2001). Dense population and industrial compounds do not hide the typical valleys and hills of this region. On the San Isidro cliffs, the "Quinta Pueyrredón" offers a view of the banks of Rio de la Plata and the lion-colored river itself. Nowadays, this property houses a Municipal Historical Museum, as it is a landmark in South American

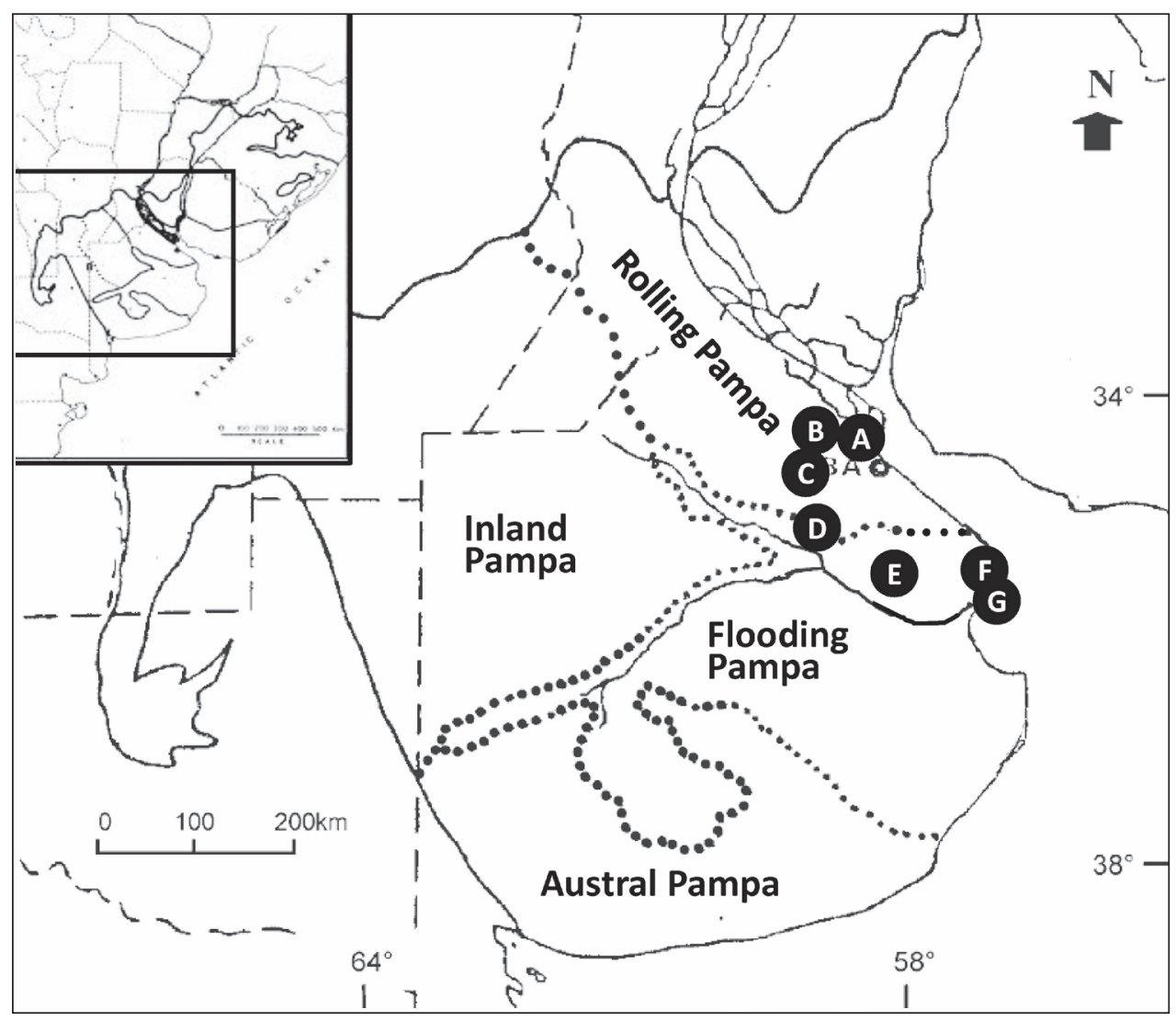

Fig. 5. A tour across the Pampas. Rolling Pampa: (a) Quinta Pueyrredón; (b) Lujan river; (c) La Blanqueada, one of the typical 'Pulperias' (countryside tabern) where gauchos gathered; (d) Tall tussock grassland remnants. Flooding Pampa: (e) Flat landscape of the Flooding Pampa. (f) Celtis ehrenbergiana (Klotzsch) Liebm.thickets (talares) over coastal strips of shell deposits; (G) Coastal marsh Spartina densiflora Brongn. grassland (adapted from Soriano \& al. 1991). 
history (http://museopueyrredon.org.ar/ Fig. 6a). The cliffs witnessed the first meetings between aboriginals and Europeans back in the early sixteenth century. In 1810, Cornelio Saavedra, a leader of the May Revolution, departed from here to establish the first Government of what later became Argentina. In the colonial style gardens, a historical tree witnessed the birth of three countries: an algarrobo (Prosopis alba Griseb.) shelters us with the same shade in which José de San Martín and Juan Martín de Pueyrredón planned the Liberating Expedition of Southern South America. In fact, trees of different species of Prosopis characteristic of the Espinal phytogeographical province are represented in the garden (P. affinis Spreng. (ñandubay), P. caldenia Burkart; Cabrera 1976), as well as other tree species from the river bank thickets such as tala (Celtis ehrenbergiana (Klotzsch) Liebm.) and ceibo (Erythrina crista-galli L.) described by the Jesuit priest Thomas Falkner (Falkner 1774). These trees provided essential fire wood for the very first settlers of Buenos Aires (D'Orbigny 1998) and are easily identified, along with the ombú (Phytolaca dioica L.), in paintings by Prilidiano Pueyrredón, the distinguished Argentine landscape painter who portrayed the Pampas in the nineteenth century - ( https://www. bellasartes.gob.ar/coleccion/obra/3170).

Continuing our journey towards the northwest, we leave the river behind and enter the Rolling Pampas. Driving along Provincial Route 41 to the city of Mercedes, we cross a landscape deeply modified by human activity. Soybean (Glycine max L.), maize (Zea mays L.), or wheat (Triticum aestivum L.) fields, and sown pastures alternate with gated neighbourhoods, malls, and industrial buildings (Fig. 6b). In the valley of the River Lujan, we find narrow corridors of grassland vegetation dominated by native grasses of the genera Nasella, Paspalum, Aristida and Piptochaetium, and shrubs of genera Baccharis, and Vernonia. The ancient atmosphere and meals from the Pampas are experienced in traditional taverns (pulperias) in San Antonio de Areco (Fig. 6c). The pulpería served as grocery store, bar, social club, and fighting arena for the rural life. "La Blanqueada" is a National Historical Museum (http://www.sanantoniodeareco.com/pulperia-la-blanqueada), as it is the setting of "Don Segundo Sombra", a traditional masterpiece of Argentine literature, written by Ricardo Güiraldes.

Our journey continues on route 41, forming a wide arch around Buenos Aires suburbs, toward the city of General Belgrano across the Salado River and into the lowlands of the Flooding Pampa. Crossing the Salado is a meaningful event as this river used to be the limit of European civilization in the Pampas, and significant historical outposts are distributed along its banks. In the Flooding Pampa, we have the opportunity to enjoy the apparent limitlessness of the plain. Sharpening our view, we might also learn to perceive and value the subtle topography of the paleo-dunes and depressions generated under desert climate during glaciation times and of shallow valleys of slow meandering watercourses (Tricart 1973; Burkart \& al.1990). In the Flooding Pampas, grasslands are usually grazed by cattle year-round, and the horizon often looks still uninterrupted by trees. There are some grassland stands dominated by Paspalum quadrifarium Lam., a native tall tussock grass known as redstraw (Fig. 6 c; Perelman \& al. 2003), that are host of a high diversity of native plant and animal species. Near the city of Castelli, we visit remnants of humid grassland communities with characteristic species like Leersia hexandra Sw., Paspalidium geminatum (Forssk.) Stapf and Carex phalaroides Kunth. (Fig. 6d).

Finally, on the trip back to Buenos Aires along PR 11, we visit the coastal landscape where strips of tala(Celtis ehrenbergiana (Klotzsch) Liebm.) thicket occupy old marine 


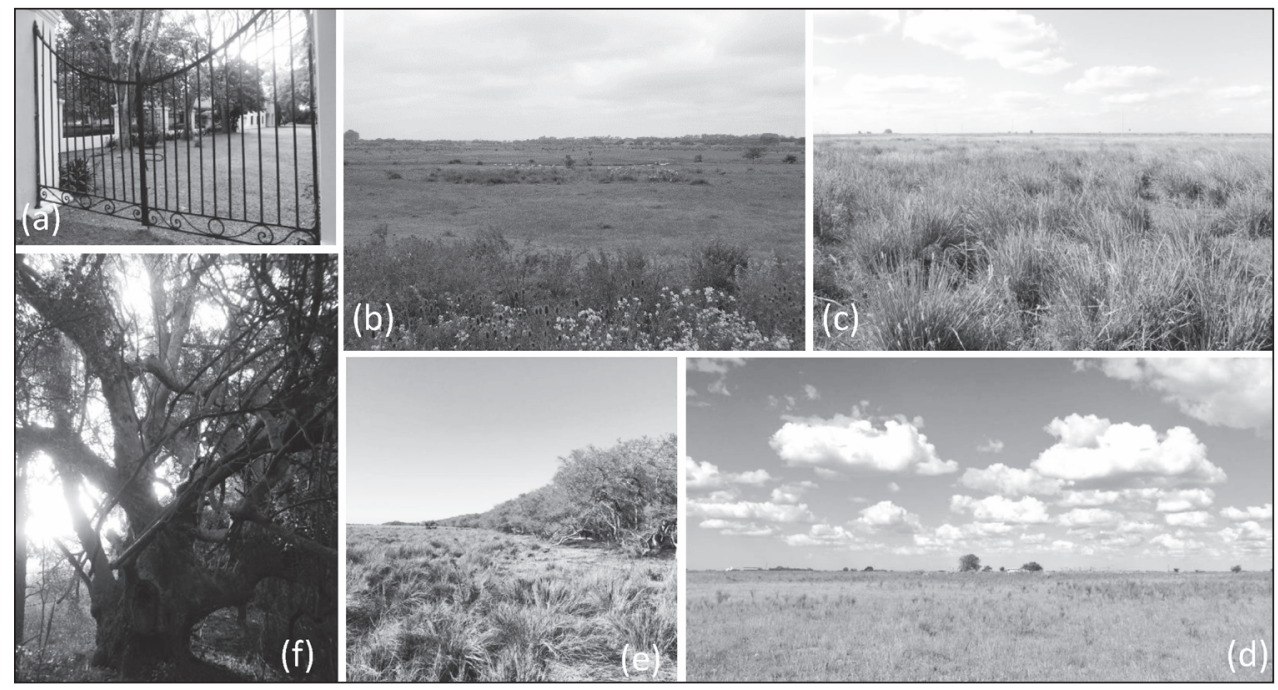

Fig. 6. Images from some the tour across the Pampas grasslands. We purposely present B\&W photos to invite future travelers to enjoy the live colours and tints of these lookouts. (a) Gates of the Quinta Pueyrredón. General José de San Martin walked through this gate before starting his military campaign to free Southern South America from Spain. (b) Valley in the Rolling Pampas seen from the upland. This region is characterized by well-defined watersheds tributaries of the Paraná river and Rio de la Plata. (c) Tall tussock grassland dominated by Paspalum quadrifarium Lam. near General Belgrano, Buenos Aires. (d) Cloudy, flat landscape, with small tree clusters surrounding houses. These trees were planted by settlers to provide shelter, shade, and wood. Later, some of the planted species have invaded the grassland. (e) Long and narrow Celtis ehrenbergiana (Klotzsch) Liebm. thicket (talar) in contact with a stand of Spartina densiflora Brongn. coastal marsh grassland. These lineal forests support a great plant and animal biodiversity, but are also prone to invasion. (f) Sun flecks inside a 'talar' inspired Sara Gallardo to one of the passages of her novel "Los galgos, los galgos” (1968). Photos: (a,f) Marina Omacini; (b-e) Pedro Tognetti.

shell deposits parallel to the coastline which alternate with lowlands covered by tall grasslands dominated by Sporobolus densiflorus Brongn. In the thickets, the dominant tala $(C$. ehernbergiana, Fig. 6f) is accompanied by molle (Schinus longifolius (Lindl.) Speg.), coronillo (Scutia buxifolia Reissek), and blanquillo (Sebastiania brasiliensis Spreng.) among other woody native species. This forest is nowadays deeply degraded as numerous native species have become infrequent while numerous invading exotics,such as ligustro (Ligustrum lucidum W.T. Aiton), acacia negra (Gleditsia triacanthos L.), almez (Celtis australis L.), mora (Morus sp. pl.), or paraíso (M. azedarach L.), often attain dominance (Fig. 6e). Between the forested strips, the $S$. densiflorus graslands (espartillares) occupy low longitudinal bands the last of which runs along the muddy coastline dug up by innumerable crabs (Fig. 6e).On returning to the city of Buenos Aires, the travellers can the aftertaste of the Pampas, with Argentine folk music by Eduardo Falú or Francisco Giacobbe, who composed under the inspiration of this wonderful grassland. 


\section{Threats to the persistence of Pampean Grassland}

As other regions over the world, the Pampas are threatened by human activities that fragment the landscape and cause deep changes in ecosystem structure and function(León \& al. 1984; Laterra 1997; Ghersa \& Leon 1999, 2001; Laterra \& al. 2003; Burkart \& al. 2005; Baldi \& al. 2006; Chaneton \& al. 2002; Tognetti \& Chaneton 2015).Transformation of the grassland into crop fields, orchards, cattle feedlots, and tree plantations, within landscapes traversed by elevated highways and artificial waterways, expose the ecosystems to exotic plants and animals and altered disturbance regimes. Under these new conditions, persistence of the Pampean grassland is seriously compromised (Tognetti \& Chaneton 2015), and the characteristic open horizon of the region might be condemned to disappear forever.

Conservation strategies for the Pampas must consider that the native grassland not necessarily regenerates after cessation of land use. Secondary succession after land abandonmentfollows contrasting pathways depending on whether previous human perturbation was livestock grazing, agriculture, or tree plantation, and depending on the characteristics of the landscape in different sub regions of the Pampas (Suding \& al. 2004; Tognetti 2010; Rodriguez \& al. 2016). While spontaneous recovery of the native vegetation appears possible in certain cases (Leon \& Oesterheld 1982; Cuevas \& Zalba 2009), post-agricultural recovery requires specific restoration intervention (Tognetti \& Chaneton 2012), because succession tends to be arrested in a state dominated by exotic plants like the wintergrass Festuca arundinacea Schreb. and the summer grasses Cynodon dactylon(L.) Persand Sorghum halepense (L.) Pers (Omacini \& al. 1995; Omacini \& al. 2005; Tognetti \& al. 2010; Tognetti \& Chaneton 2012). Our studies suggest that the dominance of these exotic species may be associated with change in the composition of the regional flora (Ghersa \& León 1999; Chaneton \& al. 2002) and with the paucity of native vegetation remnants in agricultural landscapes (Burkart \& al. 2011; Perelman \& al. 2017).Consequently, conservation of the grassland requires active management measurements specific for each sub region of the Pampas.

\section{Acknowledgements}

We dedicate this paper to the memory of Dr. Rolando León, leader of South American vegetation science over the past 50 years (Bulletin IAVS, march 2016). This study has been supported by grants from the Universidad de Buenos Aires (Programa UBACYT) and the Agencia Nacional de Promoción Científica y Tecnológica (FONCYT), Argentina. The authors thank Dr. Francesco Maria Raimondo for his kind invitation to participate in such a prestigious event to spread the knowledge on the Pampean Grasslands.

\section{References}

Andrade, B. O., Marchesi, E., Burkart, S. E., Setubal, R. B., Lezama, F., Perelman, S. B., Schneider A. A., Trevisan, R., Overbeck G. E. \& Boldrini, I. I. 2018: Vascular plant species richness and distribution in the Río de la Plata grasslands. - Bot. J. Linn. Soc. 188(3): 250-256. doi: 10.1093/botlinnean/boy063 
Baldi, G., Guerschman, J. P. \& Paruelo, J. M. 2006: Characterizing fragmentation in temperate South America grasslands. - Agric. Ecosyst. Environ. 116: 197-208. doi: 10.1016/j.agee.2006.02.009

Batista, W. B. \& León, R. J. C. 1992: Asociación entre comunidades vegetales y algunas propiedades del suelo en el centro de la Depresión del Salado. - Ecol. Austral. 2: 47-55.

—, Taboada, M. A., Lavado, R. S., Perelman, S. B. \& León, R. J. C. 2005: Asociación entre comunidades vegetales y suelos en el pastizal de la Pampa Deprimida. - Pp. 113-129 in: Oesterheld, M., Aguiar, M. R., Ghersa, C. M. \& Paruelo, J. M. (eds), La heterogeneidad de la vegetación de los agroecosistemas. - Buenos Aires.

Bond, W. J. \& Keeley, J. E. 2005: Fire as a Global "Herbivore": The Ecology and Evolution of Flammable Ecosystems. - Trends Ecol. Evol. 20: 387-394. doi: 10.1016/j.tree.2005.04.025

Borges, J. L. 1944: Ficciones. Sur. - Buenos Aires.

Burkart, S.E., León, R. J. C. \& Movia C. P. 1990: Inventario fitosociológico del pastizal de la Depresión del Salado (Provincia de Buenos Aires) en un área representativa de sus principales ambientes. -Darviniana 30: 27-69.

-, León R. J. C., Conde M. C. \& Perelman S.B. 2011: Plant species diversity in remnant grasslands on arable soils in the cropping Pampa. - Pl. Ecol. 212: 1009-1024. doi: 10.1007/s11258-010-9881-Z

—, Garbulsky, M. F., Ghersa, C. M., Guerschman, J. P., León, R. J. C., Oesterheld, M., Paruelo, J. M. \& Perelman, S. B. 2005: Las comunidades potenciales del pastizal pampeano bonaerense. - Pp. 379-399 in: Oesterheld, M., Aguiar, M. R., Ghersa, C. M. \& Paruelo, J. M. (eds), La heterogeneidad de la vegetación de los agroecosistemas. - Buenos Aires.

Busch, C. K., Mazía C. N., Hodara K. , Muschetto E. \& Chaneton, E. 2012: Rodent seed predation on tree invader species in grassland habitats of the inland Pampa. - Ecol. Res. 27: 369-376. doi: 10.1007/s11284-011-0909-1

Cabrera, A. L. 1976: Regiones fitogeográficas argentinas. Enciclopedia Argentina de Agricultura y Jardinería, 2(1). - Buenos Aires.

Chaneton, E. J., Perelman, S. B., Omacini M. \& León, R. J. C. 2002: Grazing, environmental heterogeneity, and alien plant invasions in temperate grasslands. - Biol. Invas. 4: 7-24.

-, Mazia, C. N., Batista, W. B., Rolhauser, A. \& Ghersa, C. M. 2012: Woody plant invasions in Pampa grasslands: a biogeographical and community assembly perspective. - Pp. 115-144 in: Myster, R. W. (ed), Ecotones between forest and grassland. - New York. doi: 0.1007/978-14614-3797-0_5

Chaneton, E. J., Mazia, C. N., Machera, M. Uchitel, A. \& Ghersa C. M. 2004: Establishment of honey locust (Gleditsia triacanthos) in burned Pampean grasslands. - Weed Technol. 18: $1325-1329$.

Cuevas, Y. A. \& Zalba, S. M. 2009: Control de pinos invasores en el Parque Provincial Ernesto Tornquist (Buenos Aires): áreas prioritarias y análisis de costos. - BioScriba. 2: 76-89.

Darwin, C. 1878: Geologische Beobachtungenüber Süd-America. - Angestelltwährend der Reise der Beagle in den Jahren 1832 - 1836, trad. Victor Carus. - Stuttgart.

D'Orbigny, A. 1998: Viaje por América Meridional. Buenos Aires. Translation of the historical part of Voyage dansl'Amérique Méridionale, 9 volumes published by D'Orbigny A. between 1835 \& 1847. - Paris.

Echeverría, E. 1837: La Cautiva. 1967 reprint. - Buenos Aires.

Ellenberg, H. 1962: Wald in der Pampa Argentiniens? - Ver. Geobot. Eidg. Tech. Hoch Stift. Rübel Zürich. 37: 39-56

Facelli, J. M. \& León R. J. C. 1986: El establecimiento espontáneo deárboles en la Pampa - un enfoque experimental. - Phytocoenologia 14: 263-274.

Falkner, T. S J. 1774: Descripción de la Patagonia y de las partes contiguas de la América del Sur, traducción y notas de Samuel Lafone Quevedo, estudio preliminar de Salvador Canals Frau. - Paris. 
Gallardo, S. 1968: Los galgos, los galgos. - Buenos Aires.

Ghersa, C. M. \& León, R. J. C. 1999: Successional changes in agroecosystems of the Rolling Pampa. - Pp. 487-502 in: Walker, L. (ed.), Ecosystems of disturbed ground. - Amsterdam.

— \& - 2001: Ecología del paisaje pampeano: consideraciones para su manejo y conservación. Pp. 471-553 in: Naveh, Z. \& Liberman A. S. (eds), Ecología de Paisajes. - Buenos Aires.

—, de la Fuente, E. B., Suarez, S. León, R. J. C. 2002: Woody species invasion in the Rolling Pampa grasslands, Argentina. - Agric. Ecosyst. Environ. 88: 271-278. doi: 10.1016/S01678809(01)00209-2

Gibson, D. 2009: Grasses and Grassland Ecology. - Oxford.

Hernández, J. 1872: Martín Fierro, 1986 repr. - Buenos Aires.

- 1882: Instrucción del estanciero, 2008 ed. - Buenos Aires.

Hora, R. 2018: ¿Cómo pensaron el campo los argentinos? Y cómo pensarlo hoy, cuando ese campo ya no existe. - Buenos Aires.

Hoekstra, J. M., Boucher, T. M., Ricketts, T. H. \& Roberts, C. 2005: Confronting a biome crisis: global disparities of habitat loss and protection. - Ecol. Lett. 8: 23-29. doi: 10.1111/j.14610248.2004.00686.x

Hudson, W. H., 1895: The naturalist in La Plata, 3rd ed. - London.

Laterra, P. 1997: Post-burn recovery in the flooding pampa: impact of an invasive legume. - J. Range Manag. 50: 274-277.

-, Vignolio, O., Linares, M., Giaquinta, A. \& Maceira, N. 2003: Cumulative effects of fire on a tussock pampa grassland. - J. Veg. Sci. 14: 43-54. doi: 10.1111/j.1654-1103.2003.tb02126.x

León, R. J. C. \& Oesterheld M. 1982: Envejecimiento de pasturas implantadas en el norte de la Depresión del Salado. - Un enfoque sucesional. Fac. Agr. (UBA), 3: 41-49.

— \& Anderson, D .L. 1983: El límite occidental del pastizal pampeano. Mitteilungen der Flristischsoziologischen Arbeitsgeneinschaft. - Tuexenia, Neue Serie. 3: 67-83

—, Burkart S. E. \& Movia C. P. 1979: Relevamiento fitosociológico del pastizal del Norte de la Depresión del Salado (Pcia. de Buenos Aires). - La vegetación de la República Argentina. Serie Fitogeográfica, 17. - Buenos Aires.

—, Rusch, G. M. \& Oesterheld, M. 1984: Pastizales pampeanos - impacto agropecuario. Phytocoenologia 12: 201-218.

Mazia, C. N., Tognetti P. M., \& Cirino, E. D. 2013: Patch identity and the spatial heterogeneity of woody encroachment in exotic dominated old field grasslands. -Pl. Ecol. 214: 267-277. doi: 10.1007/s11258-013-0166-1

—, Chaneton, E. J., Ghersa, C. M., León, R. J. C. 2001: Limits to tree species invasion in pampean grassland and forest plant communities. - Oecologia. 128(4): 594-602. doi: 10.1007/s004420100709

—, - Machera, M., Uchitel, A., Feler, M. V. \& Ghersa, C. M. 2010: Antagonistic effects of largeand small-scale disturbances on exotic tree invasion in a native tussock grassland relict. - Biol. Inv. 12: 3109-3122. doi: 10.1007/s10530-010-9702-2

Omacini, M., Chaneton, E. J., León, R. J. C. \& Batista, W. B. 1995: Old-field successional dynamics on the Inland Pampa, Argentina. - J. Veg. Sci. 6: 309-316.

-, Tognetti, P. M., Trebino, H. \& Chaneton E. J. 2005: Sucesión postagrícola en la Pampa Interior: invasión y dominancia de plantas exóticas durante los primeros 20 años. - Pp. 215-234 in: Oesterheld, M., Aguiar, M., Ghersa, C. M. \& Paruelo, J. (eds), La heterogeneidad de la vegetación de los agroecosistemas. Un homenaje a Rolando León. - Buenos Aires.

Oyarzabal M., Clavijo J., Prado D., Biganzoli F., Tognetti P. M., Barberis I., Maturo H. M., Oakley L., Aragón R., Campanello P. I., León R. J. C. \&Oesterheld M. 2018: Unidades de Vegetación de la Argentina. - Ecol. Austral. 28: 40-63. doi: 10.25260/EA.18.28.1.0.399 
Parodi, L. R. 1940: Distribución geográfica de los talares de la Pcia. de Buenos Aires. - Darwiniana 4: 33-56.

— 1947: La estepa pampeana. - Pp. 143-207 in: Hauman, L., Burkart, A., Parodi, L. R., and Cabrera, A. L. (eds), La Vegetación de la Argentina. Geografía de la República Argentina, 8. - Buenos Aires.

Perelman, S. B., Burkart, S. E. \& León, R. J. C. 2003: The role of a native tussock-grass (Paspalum quadrifarium) in structuring plant communities in the Flooding Pampa grasslands, Argentina. - Biodiv. Conserv. 12: 225-238.

—, León, R. J. C. \& Oesterheld, M. 2001: Cross-scale vegetation patterns of Flooding Pampa grasslands. - J. Ecol. 89: 562-577. doi: 0.1046/j.0022-0477.2001.00579.x

—, Chaneton, E. J., Batista, W. B., Burkart, S. E. \& León, R. J. C. 2007: Habitat stress, species pool size, and biotic resistance influence exotic plant richness in the Flooding Pampa grasslands. J. Ecol. 95: 662-673. doi: 10.1111/j.1365-2745.2007.01255.x

—, Burkart S. E., Oyarzabal M., Bagnatto C. \& Batista W. B. 2017: Climatic and land-use drivers along a latitudinal gradient: species diversity in temperate grasslands on agricultural soils. - J. Veg. Sci. 28: 1230-1239. doi: 10.1111/jvs.12578

Poggio, S. L., Perelman, S. B., Mollard, F. P. O. \& León, R. J. C. 2015: Guests and gatecrashers in a New World's banquet: Old World plant species introduced from the Mediterranean Basin enriched the flora of grasslands and croplands in the Pampas of Argentina. - Fl. Medit. 25(Special Issue): 39-54. doi: 10.7320/FlMedit25SI.039

Puhl, L. E., Perelman, S. B., Batista, W. B., Burkart, S. E. \& León, R. J. C. 2014: Local and regional long-term diversity changes and biotic homogenization in two temperate grasslands. - J. Veg. Sci. 25: 1278-1288. doi: 10.1111/jvs.12179

Rodríguez, A., Jacobo, E., Roitman, G., Miñarro, F., Preliasco, P. \& Beade, M. 2016: Manejo de la oferta forrajera en el Parque Nacional Campos del Tuyú y en campos ganaderos vecinos para la conservación del venado de las pampas. - Ecol. Austral. 26(2): 150-165.

Sankaran, M., Ratnam, J. \& Hanan, N. 2008: Woody cover in African savannas: the role of resources, fire and herbivory. - Global Ecol. Biogeogr. 17: 236-245. doi: 10.1111/j.14668238.2007.00360.x

Sarmiento, D. F. 1874: Facundo. - Buenos Aires.

Sbarra, N. H. 1964: Historia del Alambrado en la Argentina. - Buenos Aires.

Schmider. 1929: The Pampa, a Natural or Culturally Induced Grass-land? - Berkeley.

Soriano, A. 1992: Río de la Plata grasslands. - Pp. 367-407 in: Coupland, R. T. (ed.), Ecosystems of the World 8a, Natural Grasslands. - Amsterdam, London, New York, Tokyo.

Suding, K. N., Gross, K. L. \& G. R. Houseman 2004: Alternative states and positive feedbacks in restoration ecology.- Trends Ecol. Evol. 19: 46-53. doi: 10.1016/j.tree.2003.10.005

Tognetti P. M. 2010: Mecanismos de sucesión en pastizales: dispersión, disponibilidad de recursos y competencia. - Tesis para optar al grado de Doctor de la Universidad de Buenos Aires

— \& Chaneton, E. J. 2012: Invasive exotic grasses and seed arrival limit native species establishment in an old-field grassland succession. - Biol. Invas. 14: 2531-2544. doi: 10.1007/s10530-012-0249-2.

- \& - 2015: Community disassembly and invasion of remnant native grasslands under fluctuating resource supply. - J. Appl. Ecol. 52: 119-128. doi: 10.1111/1365-2664.12349

—, - Omacini, M., Trebino, H. J. \& León, R. J. C. 2010: Exotic vs. native plant dominance over 20 years of old-field succession on set-aside farmland in Argentina. - Biol. Conserv. 143: 2494-2503. doi: 10.1016/j.biocon.2010.06.016.

Tricart, J. L. F. 1973: Geomorfología de la Pampa Deprimida. - Buenos Aires

Viglizzo, E. F., Frank, F. C., Carreño, L.V., Jobbagy, E.G., Pereyra, H., Clattz, J., Pince, D. \& Ricard, M. F. 2011: Ecological and environmental footprint of 50 years of agricultural expansion in Argentina. - Global Change Biol. 17: 959-973. doi: 10.1111/j.1365-2486.2010.02293.x 
Walter, H. 1967: The pampa problem and its solution. - Amsterdam.

- 1970: Vegetationenzonen und Klima. - Stuttgart.

Yazawa T. 1989: The Pampa problem: a critical review. - Geogr. Rev. Japan. 62: 389-408.

Zalba, S. \& Villamil, C. 2002: Woody Plant Invasion in Relictual Grasslands. - Biol. Invas. 4: 55-57.

Addresses of the authors:

Susana B. Perelman, Marina Omacini, Pedro M. Tognetti \& William B. Batista, Universidad de Buenos Aires, Facultad de Agronomía, IFEVA: UBA-CONICET.Av. San Martín 4453 CABA, Argentina. E-mails: perelman@agro.uba.ar, omacini@agro.uba.ar, tognetti@agro.uba.ar, batista@agro.uba.ar 
